\title{
Impact of climate change on human health and health systems in Tanzania: a review
}

\author{
LEONARD E.G. MBOERA, BENJAMIN K. MAYALA, ELININGAYA J. KWEKA and HUMPHREY D. MAZIGO \\ National Institute for Medical Research, P.O. Box 9653, Dar es Salaam, Tanzania \\ Tropical Pesticide Research Institute, P.O. Box 3024, Arusha, Tanzania \\ Catholic University of Health and Allied Sciences-Bugando, Mwanza, Tanzania
}

\begin{abstract}
Climate change (CC) has a number of immediate and long-term impacts on the fundamental determinants of human health. A number of potential human health effects have been associated either directly or indirectly with global climate change. Vulnerability to the risks associated with CC may exacerbate ongoing socio-economic challenges. The objective of this review was to analyse the potential risk and vulnerability in the context of climate-sensitive human diseases and health system in Tanzania. Climate sensitive vector- and water-borne diseases and other health related problems and the policies on climate adaptation in Tanzania during the past 50 years are reviewed. The review has shown that a number of climateassociated infectious disease epidemics have been reported in various areas of the country; mostly being associated with increase in precipitation and temperature. Although, there is no single policy document that specifically addresses issues of CC in the country, the National Environmental Management Act of 1997 recognizes the importance of $\mathrm{CC}$ and calls for the government to put up measures to address the phenomenon. A number of strategies and action plans related to $C C$ are also in place. These include the National Biodiversity Strategy and Action Plan, the National Action Programme, and the National Bio-safety Framework. The government has put in place a National Climate Change Steering Committee and the National Climate Change Technical Committee to oversee and guide the implementation of CC activities in the country. Recognizing the adverse impacts of natural disasters and calamities, the government established a Disaster Management Division under the Prime Minister's Office. Epidemic Preparedness and Response Unit of the Ministry of Health and Social Welfare is responsible for emergency preparedness, mostly disease outbreaks. However, specific climate changes associated with human health issues are poorly addressed in the MoHSW strategies and the national health research priorities. In conclusion, CC threatens to slow, halt or reverses the progress the country has made or is making to achieve its national and millennium development goals. It is therefore important that Tanzania prepares itself to appropriately address CC impact on human health. It is equally important that policy makers and other stakeholders are engaged in a process to update and adapt priorities, mobilize resources and build interdisciplinary research and implementation capacity on climate change and its mitigation.
\end{abstract}

Keywords: climate change, health, health systems, diseases, adaptation, mitigation, policy, Tanzania

\section{Background}

Global climate change, largely a result of ozone layer depletion, is caused by human activities that release greenhouse gases that trap heat within the atmosphere. These human activities include increased use of fossil fuel, land use change and agriculture (Watson et al., 1998). An increase in greenhouse gases leads to increased warming of the atmosphere and the Earth's surface. As the concentration of these gases in the atmosphere increases, climate models project that the average surface temperature will rise by $1.1^{\circ} \mathrm{C}$ to $6.4{ }^{\circ} \mathrm{C}$ in the $21^{\text {st }}$ century, with extremes potentially occurring beyond this range (IPCC, 2007; Omumbo et al., 2011). These changes are likely to have significant impacts on the fundamental determinants of human health, most notably on the ecosystems and these impacts will be added to existing health burdens.

Tanzania has been experiencing real and visible impacts of climate change. The Initial National Communication has reported that the mean annual temperatures will increase by $2.1^{\circ} \mathrm{C}$ to $4^{\circ} \mathrm{C}$ in the northern, central and southern parts of the country by 2100 . This increase will markedly be observed particularly during the cool months. During the same period of time, an annual increase by $10 \%$ in precipitation is expected. Climate projections indicate that northern and southern parts of the country would experience an increase in rainfall ranging from $5-45 \%$ and that most parts of the country might experience a decrease in rainfall of 10-15\% (Mwandosya et al., 1998). 
Changes in temperature and precipitation resulting in changes in soil moisture, increases in sea level and more extreme weather events, such as floods and droughts are among the most known impacts of global climate change (IPCC, 2001; WHO 2009). During the past three to five decades, there has been a steady increase in temperature, adversely affecting almost all sectors of the economy. Several droughts have been recurrent while water levels in Lakes Victoria, Tanganyika, Rukwa, Manyara and many other small lakes have dropped significantly. Rise in sea levels has been experienced in Tanzania, with Islands of Maziwi (in Pangani) and Fungu la Nyani (on the Rufiji River estuary) been already submerged due to rise in sea level. It is predicted that islands of Zanzibar and Mafia are likely to be submerged by 2100 following rise in sea level caused by melting of polar ice (Urama \& Ozor, 2010). Mount Kilimanjaro, the highest mountain in Africa, is undergoing rapid transformation since 1912. The snow-capped mountain is losing its glacial top at an astounding rate; and it is expected that within the next 10-20 years, the summit will be bare (Thompson et al. 2007).

The major impacts of climate change include severe floods, frequent and prolonged droughts, rising sea levels, crop failure, loss of livestock, lower water availability and quality and an increase in vector and water-borne diseases (Githeko et al., 2000; Patz et al., 2005). Heavy rains, floods, drought and landslides in Tanzania have resulted into internal displacement, food shortages and increased disease transmissions. Drought itself has significantly contributed to malnutrition due to lack of adequate food, increased infectious diseases transmission and scarcity of clean and safe water (Kandji \& Verchot, 2005). Land slides, droughts and floods are becoming common in Tanzania. In recent years (2009-2011), heavy rains accompanied with strong winds have left thousands of people displaced and without food in Muleba, Kilosa, Same and Dar es Salaam. The flooding of 2009/2010 in Kilosa proved as serious that over three quarters of the farmers reported their households were affected. One-third of the households were displaced from their homes, with some still displaced two years later (Fahey et al., 2011). In October 2009, northern Tanzania lost between 3,000 and 4,000 cattle in a decade's worst drought (http://www.citizenjournalismafrica.org/). In December 2011, the capital city of Dar es Salaam, experienced the heaviest rains since 1954 (http://www.dailynews.co.tz/home) causing floods in most of its parts resulting into loss of about 40 people (http://www.ippmedia.com/). Similarly, the severe drought of 2007/2008 which was followed by abnormal heavy rainfalls resulted in the outbreak of Rift Valley Fever epidemic in Tanzania (Mohamed et al., 2010.

Although the impacts of climate change are global, the most vulnerable are the poor and marginalized people from developing countries who depend most directly on their ecosystems for survival. These are the same people who have the least capacity to adapt to the rapid changes that are affecting their environment (WHO, 2008), who do not have access to adequate safe water, adequate sanitation and lack access to land, credit or knowledge (www.thelancent.com).

Climate change-related impacts on the ecosystems are likely to affect population by creating favourable conditions for disease vectors or disease pathogens as well as placing the communities at high risk of malnutrition, diarrhoeal diseases and other environmental health effects attributable to climate change (Ebi et al., 2007). There is important evidence to show that climate change affect the occurrence and distribution of human diseases and malnutrition. Changes in the frequency and spread of infectious diseases are some of the most widely documented potential effects of climate change, and could have significant consequences for human health as well as economic and societal impacts (Chan et al., 1999). Based on this fact, In May 2008, the World Health Assembly (WHA) passed a resolution calling for a stronger commitment of Member States and the World Health Organization to protect health from climate change (www.who.int/globalchange/climate/EB CChealth_resolution/en/index.html). In response to the WHA resolution, WHO convened a global consultation of public health researchers, practitioners, representatives of UN and other stakeholders, to respond to this request. The WHA resolved and agreed, among others, that research on climate change and health is within the overall context of improving global health, and health equity; that improved risk assessment is necessary to inform 
decision makers on health impacts from climate change locally as well as globally. The objective of this review was therefore, to analyse the nature of risk and vulnerability in the context of climatesensitive human diseases and health system in Tanzania and to identify national policies that address climate change issues. The paper further discusses the ways of mainstreaming and integrating adaptation to climate change into poverty reduction and sustainable socio-economic development efforts. This paper was written through desktop review of key policy documents, technical reports, publications and available internet based literature.

\section{Impacts of Climate Change on Human Health}

The prevalence of some of the tropical diseases and other threats to human health depend largely on local climate. According to the Intergovernmental Panel on Climate Change (IPCC, 2007), extreme temperatures can lead directly to loss of life, while climate-related disturbances in ecological systems can indirectly impact the incidence of infectious diseases. On the other hand, warm temperatures can increase air and water pollution, which in turn harm human health. Extreme weather can destroy shelter, contaminate water supplies, cripple crop and livestock production, tear apart existing health and other service infrastructures. This will ultimately increase the existing burden of disease and other non-health need of vulnerable human population. The magnitude and nature of climate change impacts on human health vary by region, by relative vulnerability of population groups, by the extent and duration of exposure to climate change itself and by society's ability to adapt to or cope with the change (IPCC, 2007).

Climate change can affect human health and well-being through a variety of mechanisms (Githeko et al., 2000; Patz et al., 2005; Afrane et al., 2006). The risk of emerging diseases may increase due to changes and survival of pathogens in the environment, changes in migration pathways, carriers and vectors and changes in the natural ecosystems (Afrane et al., 2006). Infectious agents are in a state of perpetual adaptation to their new host (s) or vectors, which can lead to the emergence of 'new' diseases or the spread of known diseases to previously unaffected areas. Factors that lead to the adaptation of infectious agents are complex and dynamic, ranging from deforestation, irrigation, species competition, human and animal migration patterns, drug resistance and changing vector lifecycle due to variations in temperature and rainfall (Patz et al., 2005; Afrane et al., 2006). The climate sensitive infections have some commonalities; they are focal, and their distribution is limited by the ecology of their vectors or reservoirs. Usually, the range of the vectors or reservoirs is delineated by temperature and sometimes availability of water bodies (Shope, 1992). Predicted changes in climate and climate impacts will have direct and indirect impacts on human health. Warming is predicted to increase or decrease the incidence of vector-borne diseases. The increased frequency of droughts and flooding is in turn likely to increase the frequency and magnitude of epidemics of water-borne diseases, as well as to influence the incidence of vectorborne diseases. Warming will also aggravate the impacts of air pollution on respiratory illnesses (McMichael et al., 1996; Githeko et al., 2000; IPCC, 2001; Patz et al., 2005; Afrane et al., 2006).

\section{Climate-Sensitive Diseases in Tanzania}

Alterations to the natural environment may change the context within which pathogens, vectors and their hosts interact, thus potentially affecting vector or water-borne disease epidemiology (Vora, 2008). Human-driven ecological changes have been incriminated to be contributing to the spread of vector-borne diseases. Such changes include deforestation, agriculture and animal husbandry, water control projects, urbanization, loss of biodiversity, introduction of alien species, and climate change (Vora, 2008). Vector-borne diseases are particularly sensitive to climate change because temperature and precipitation changes can alter vector development rates, shift their geographical distribution and alter transmission dynamics. As a result of anthropogenic climate change on vector-borne 
diseases remains debated, there appears to be an overall expansion of the global distributions of malaria, various mosquito- and tick-borne encephalitides, and yellow fever that is at least partially attributable to rising global temperatures (Chivian \& Bernstein, 2004). Vector-borne and water-borne diseases are the most important climate-sensitive diseases reported in Tanzania. These include malaria, rift valley fever, dengue fever, trypanosomiasis, plague, schistosomiasis and diarrhoeal diseases. The IPCC has noted that the global population at risk from vector-borne diseases will increase by between 220 million and 400 million in the next century. Most of this increase is predicted to occur in Africa (IPCC, 2007). Similarly, water-borne diseases may increase where warmer air and water temperatures combine with heavy runoff from agricultural and urban surfaces (Patz et al., 1996; IPCC, 2007).

Mosquito-borne diseases, including malaria, rift valley fever and dengue are among those diseases most sensitive to climate (Patz et al., 1996) and are among the most important vectorborne diseases in the tropics and subtropics. Climate change is most likely to affect free living, intermediate, or vector stages of these human pathogens. Climate change has impact on the abundance and geographical range of tropical disease vectors; this is due to the fact that rising temperatures affect vector distribution, parasite development and transmission rates (Kovats et al., 2001). Climate change directly affects disease transmission by shifting the vector's geographic range and increasing reproductive and biting rates and by shortening the pathogen incubation period (Patz et al., 1996).

\section{Malaria}

Malaria is by far the most important vector-borne disease causing high morbidity and mortality in Tanzania. The endemicity and pattern of malaria transmission is focal and varies from place to place depending on many factors including climate and topography. Until recently, malaria has been a common disease in low altitude rural areas of Tanzania (Clyde, 1967). However, due to changes in socio-economic, environmental, and vector related factors, the disease is now common in previously malaria-free highland areas (Mboera \& Kitua, 2001; Mboera, 2004). Modelling malaria endemicity in Tanzania using an outpatient cases (2004-2008) in relation to mean temperature and mean precipitation has shown that almost the whole of Tanzania is endemic for malaria, with spatial variation between areas. Mean precipitation accounts for $72.8 \%$ of the variation in malaria, while mean maximum temperature accounts for $14.1 \%$ and mean minimum temperature $13.1 \%$ (Mboera et al., 2010). The geographical expansion of malaria in East Africa has been associated with increased in ambient temperature. Warmer temperatures have impact on the rates at which mosquitoes reach sexual maturity, frequency of mosquito blood meals, and rates at which parasites are acquired, as well as shortened incubation time of parasites within mosquitoes (Vero, 2008). On the other hand, increased precipitation associated with global warming may result into increased in number of breeding sites and hence, mosquito populations (Patz et al., 2000; Harrus \& Baneth, 2005).

Studies in north-east Tanzania have shown that ecological changes that occurred in the East and West Usambara mountains played a significant role in the increase of malaria transmission in the area (Matola et al., 1987; Bodker et al., 2003, 2006). Increase in ambient temperature has been associated with malaria epidemics in other areas of East Africa. In a study conducted in Mpwapwa district in central Tanzania it was found that the malaria epidemic of 1999 was directly associated with climatic factors, particularly rainfall and temperature. During this year, the district experienced the highest temperatures and a prolonged period of rainfall (Mboera et al., 2005). Mpwapwa district is located in the central plateau of Tanzania and is usually semi arid with a short period of rainfall occurring between December and April. Further climate-linked malaria epidemics have been reported elsewhere in East Africa (Matola et al., 1987; Loevisohn, 1994; Mboera \& Kitua, 2001). Recently, Jones et al. (2007) carried out a regression analysis on retrospective malaria and climatic data during annual malaria seasons and found that high malaria incidence was associated with 
increased rainfall and temperature. In Mbeya Region, Kangalawe (2009) has demonstrated a clear association between temperature trends and malaria incidences as an impact of climate change.

A common characteristic of many affected areas prior to the malaria epidemics is that they had suffered a recent period of drought and were recognised as having serious food security problems (WHO, 2001). Further support for the link between food security issues and epidemic malaria comes from the study in Mbulu District in 1942 (Clyde, 1967) and Muleba District in 1978 (Garay, 1998). The risk of mortality from malaria during the Muleba epidemic was observed to be seven times higher in malnourished than well nourished children giving support to the view that the consequences of epidemic malaria are most intensely felt in communities where food entitlement is constrained. Findings of some studies have suggested that a delay in seeking medical care has contributed highly to loss of life (Mboera et al., 1999). Such delays have been aggravated by destruction of the infrastructure as it was observed in Muleba district during the 1978 malaria epidemics (Garray, 1998).

The impact of climate change on malaria has been described in a number of studies in Africa (Lindsay \& Birley, 1996; Lindsay \& Martens 1998; Lindsay et al., 1998, 2000). The impact of climate variability and malaria can be explained by the fact that as altitude increases, temperature declines and both the development and survival of the mosquito vector and parasite are critically dependent on the ambient temperature. As the temperature drops so does the risk of infection, and there is a typical threshold below which transmission ceases.

Anopheles gambiae complex and A. funestus mosquitoes are responsible for transmission of most malaria in Tanzania. These species of mosquitoes are sensitive to temperature changes both as adults and immature stages in the aquatic environment (Rueda et al., 1990). When water temperature rises, the immature stages take a relatively shorter time to mature and consequently there is a greater capacity to produce more offspring during the transmission period (Rueda et al., 1990). In warmer climates, the gonotrophic cycle of Anopheles mosquitoes is shorter, this means the adult female mosquitoes digest blood faster and feed more frequently, thus increasing transmission intensity (Gillies, 1953). Similarly, malaria parasites complete extrinsic incubation within the female Anopheles mosquito in a shorter time as temperature rises thereby increasing the proportion of infective vectors (Turell, 1989).

The distribution of Anopheles gambiae complex siblings is determined by ecological factors. While Anopheles gambiae prefers the wet and humid zones, An. arabiensis has adapted to drier climates (Coluzzi et al., 1979). It has been reported by Lindsay et al. (1998) that the distribution and relative abundance of these species can be predicted fairly accurately using climate models and could be used to indicate future changes in vector distributions associated with changing climate. On the other hand, increased precipitation has the potential to increase the number and quality of breeding sites for mosquitoes.

\section{Rift Valley Fever}

Rift Valley fever (RVF) is a climate-related infection and all outbreaks in East Africa have been reported to occur following periods of abnormal drought, followed by abnormal heavy rains and the consequent emergence of large numbers of Aedes and Culex mosquitoes (Linthicum et al., 1985; 1998; Hightower et al., 2012).). RVF epidemics in Tanzania have been recorded to occur in 1956, 197879, 1997-98 and 2007. In January 2007, an outbreak of RVF was detected among humans starting from northern Tanzania districts, but later spreading southwards and westwards to affect other parts of the country. A total of 511 suspect RVF cases were reported from 10 of the 21 regions of Tanzania, with laboratory confirmation of 186 cases and another 123 probable cases. All RVF cases were located in the north-central and southern regions of the country, with an eventual fatality rate of $28.2 \%(N=144)$ (Unpublished Report, Ministry of Health and Social Welfare). While the 1997-98 epidemics were confined in Arusha region in northern Tanzania, the 2007 epidemics spread south and west-wards to cover a number of regions (Mohamed et al., 2010). 


\section{Dengue fever}

Dengue fever is considered as the most important arbovirus disease throughout the World. The disease is prevalent throughout the tropics and subtropics and is more important in highly urbanized communities with poorly managed water and solid waste systems. Although the history of dengue in Africa is poorly documented, it is known that the disease has been on the continent since the start of the $20^{\text {th }}$ century. A retrospective serosurvey by Kokernot et al., (1956) suggests that dengue in Africa existed as far back as 1926-1927, when it caused an epidemic in South Africa. The first description of Dengue virus serotype 3 (DENV-3) activity in Africa was related to outbreaks detected during 1984 and 1985 in Pemba, Mozambique, with two deaths due to dengue haemorrhagic fever (Vasilakis et al., 2008). DENV-3 was then detected in 1993 in Somalia and areas around the Persian Gulf (Gubler \& Clark, 1995).

Despite poor surveillance for dengue in Africa, it is clear that epidemic dengue fever caused by all four dengue serotypes has increased dramatically since 1980, with most epidemics occurring in eastern Africa (Gubler, 2000). Tanzania recorded the first outbreak of dengue fever in Dar es Salaam in February 2010. The cases were from five tourists who were returning to Europe and Japan. The cases were confirmed by PCR to be Dengue fever type 3 virus (DENV-3) infections. Later in May 2010, more cases of dengue fever were reported from hospitals in Dar es Salaam. Out of 126 samples collected, 46 were positive for dengue fever (18 among them being Tanzanians) (Ministry of Health and Social Welfare, unpubl). Unfortunately, the burden of dengue virus infection in Tanzania is not known with certainty. In a recent study in Mbeya in south-western Tanzania, a 6\% seroprevalence of DENV 1-4 was reported in Mlowo area (Weller et al. 2010).

Dengue viruses, like all other arboviruses are transmitted in nature primarily by arthropods to vertebrates. The virus is transmitted to human by mosquitoes, especially Aedes aegypti and Aedes albopictus. Aedes aegypti is highly domestic and a day-biting species that prefers to feed on humans. Generally, small and inconspicuous containers of water, both natural and artificial, such as discarded cans and cups, roof gutters, barrels, flower pots, tree holes, water tanks, or tires are used as breeding sites for these vectors. Although the lifespan of an adult Aedes aegypti is between two to four weeks depending on conditions, Aedes aegypti's eggs can be viable for over a years in a dry state, which allows the mosquito to re-emerge after a cold or dry spell. The increase risk and resurgence of dengue in many parts of the world is associated with urbanization, increased travel, and climate change (http://www.climatecentral.org/blogs/the-climate-connection-to-dengue-fever/). Temperature is known to influence adult survival, the lengths of the gonotrophic cycle and the extrinsic incubation period of the virus in the vector, and vector size, a factor that indirectly influences the biting rate (Jetten \& Focks, 1997). The current warming projection of the International Council of Scientific Unions and the Intergovernmental Panel on Climate Change of $2^{\circ} \mathrm{C}$ by the end of the next century is expected to result in a potential increase in the latitudinal and altitudinal range of dengue (Jetten \& Focks, 1997). A model by Hales et al. (2002) has already predicted that dengue fever incidence will increase worldwide secondary to climate change.

Information on other arboviral climate sensitive infection in Tanzania is scarce. Only few studies have been carried out on arbovirus infections in Tanzania (Crabtreee et al., 2007). An outbreak of O'nyong-nyong fever was reported from Bukoba district in North-western Tanzania in late 1996 (Rwaguma et al., 1997). In an investigation carried out in Mwanza in 1966-1967, Chikungunya virus was detected in $73 \%$ of the 78 sera of human beings. This high seroprevalence was thought to be due to the epidemic of O'nyong-nyong fever that occurred in East Africa in 1958 (Fukumi et al., 1967). The outbreak of O'nyong-nyong fever started in northern Uganda and spread south and eastward into Kenya, Tanzania, and Zambia (Rwaguma et al., 1997). At least one other arbovirus, Bwamba virus (Bunyamwera group), was detected in a refugee camp in north-western Tanzania (Lutwama et al. 2002). Recent studies in Mbeya Region have also reported high prevalence of antibodies against Chikungunya virus (48\%) and flaviviruses (West Nile virus, Dengue viruses 1-4, yellow fever virus) ranged between $20 \%$ and more than $30 \%$. All these findings indicate circulating 
antibodies of arboviruses among Tanzanian populations, hence have been infecting humans (Weller et al. 2010). Acute Chikungunya virus infections have been recently confirmed among $7.9 \%$ patients with febrile illness in northern Tanzania. Chikungunya virus infection was more common among infants and children than adults and adolescents and among HIV-infected patients with severe immunosuppression (Hertz et al., 2012).

\section{Human African Trypanosomiasis (HAT)}

HAT in Tanzania is caused mainly by Trypanosoma brucei rhodesiense and transmitted by tsetsefly of Glosina species. Glossina morsitans morsitans have adapted to ecosystems ranging from humid forests to dry savannas; whereas $G$. palpalis is a riverine species preferring to rest under dense vegetation close to river banks. As these ecosystems changes, so does the distribution of vectors species. Factors that alter the resting sites for adult tsetse flies, such as long-term changes in rainfall and temperature, can affect the epidemiology and transmission of trypanosomiasis (Githeko et al., 2000; Moore et al., 2011). Combining a variety of direct effects of temperature on vector ecology, vector biology and vector-parasite interactions via a disease transmission model, Moore et al. (2011) have extrapolated the potential compounding effects of projected warming on the epidemiology of HAT. Using the model, Moore et al. (2011) predict that HAT epidemics can occur when mean temperatures are between $20.7^{\circ} \mathrm{C}$ and $26.1^{\circ} \mathrm{C}$ - causing a large shift of up to $60 \%$ in the geographical extent of the range. The model also predicts that $46-77$ million additional people may be at risk of HAT exposure by 2090.

Livestock and human mobility and environmental dynamics that influence tsetse fly presence, density and dispersal are known to play role on the geographical extent of HAT foci (Courtin et al., 2008). Deforestation that has been going on in HAT endemic region of Tanzania has been associated with drought and decrease in precipitation. This is likely in turn to affect the survival of immature tsetse stages, and hence affecting the population and transmission of sleeping sickness. It is important therefore, to understand how environmental modifications, population dynamics and climate change will impact on the distribution and incidence of the disease. Change in climate and vegetation are among factors that have been associated with the reemergence of HAT (WHO, 1986).

\section{Schistosomiasis}

Schistosoma mansoni and S. haematobium infections are prevalent in Tanzania (Lwambo et al., 1999; Brooker et al., 2001; Lwambo, 2005). The life cycle of the parasite is complex involving snails, water, and human beings. The cycle is susceptible to environmental change, especially in water-associated stages. The intermediate hosts of S. hematobium are Bulinus snails, those of S. mansoni are Biomphalaria snails. A major determinant of schistosome distribution is the distribution of their intermediate snail host. Snail populations are dependent on physical and biological factors such as temperature, water, food availability, water $\mathrm{pH}$, snail population, diseases and water currents. Studies have established that ambient temperature is an important limiting factor of the survival of snails and of the shedding of cercariae (lijima \& Sugiura, 1962). This means that rapid increase in ambient temperature is likely to affect the survival of parasite and therefore schistosomiasis may disappear in some foci. Areas of East African coast already have high temperatures, and it has been suggested that this is the reason why the members of the genus Biomphalaria snail has not colonized the zone (Sturrock, 1965). In Kenya, a major drought from 2001 to 2009 resulted into the drying of ponds that were known previously as sources of infection for $\mathrm{S}$. haematobium. These changes in the transmission patterns or disappearances of intermediate hosts in transmission ponds was the implications of extreme weather and changes in climate conditions on the risk and transmission of $S$. haematobium (Mutuku et al., 20110). On the other hand, other areas in highlands, now too cold to support the host snails, can be expected in the future to be favourable ecologically for schistosomiasis. In a study in Tanzania by Marti et al. (1985), rainfall patterns have a distinct influence on Bulinus globosus densities. A similar phenomenon was later established by Woolhouse \& 
Chandiwana (1990) in a simulation model using data collected from Zimbabwe. Long-term changes in precipitation can therefore be expected to alter the distributions of snails and in turn the disease pattern (Githeko et al., 2000).

\section{Leptospirosis}

This is another climate-related disease. Leptospirosis is a globally important zoonotic disease, most commonly found in tropical or sub-tropical countries and may be prevalent in both urban and rural settings (http://www.agribusinessweek.com/climate-change-triggers-leptospirosis-outbreaks/). The epidemiological status of human leptospirosis in Tanzania has not been well defined because of a general lack of awareness of the disease and difficulties in its diagnosis. However, a recent study among various occupational groups in north-east Tanzania reported a prevalence of $15.1 \%$ (Schoonman \& Swai, 2009). The serovar Icterohaemorrhagiae, Bataviae, Hardjo, Tarrassovi, Ballum and for Pomona were found in the studied population. Livestock farmers, veterinarians and abattoir workers were most at risk. Poor sanitation and the increase in urban slums along with frequent typhoons and expansion of flooding areas in the country have exacerbated the risk of infection. In another study, Biggs et al. (2011) found a prevalence of $8.8 \%$ leptospirosis among admitted patients in two hospitals in Moshi, Tanzania. They concluded that Leptospirosis is a major yet underdiagnosed cause of febrile illness in northern Tanzania. Previous findings in Tanzania (Machang'u et al., 1997, 2003) showed that leptospirosis is much more common than generally thought.

Leptospirosis is spread through the urine of infected animals, which gets into water or soil and can survive there for weeks or even months. Animals become infected through direct contact with contaminated water or soil. Humans can be infected with leptospirosis in ways similar to animals, which are in direct contact with contaminated water or soil, ingestion (oral), or inhalation (aerosol). Humans can also be exposed through direct contact with the urine of infected animals. The incidence of infection is seasonal, in tropical countries, the peak incidence occurs during the rainy season. The prevalence of leptospirosis is generally high in domestic animals and rodents in Tanzania. Recently, scientists at Sokoine University of Agriculture have identified a new strain of Leptospira kirchners serovar Sokoine (Mgonde et al., 2006).

\section{Plague}

Plague is a rapidly progressing, serious and highly fatal infectious disease of humans (Gage \& Kosoy, 2005; Stenseth et al., 2008). It is a disease of public health importance in Tanzania (Kilonzo et al., 1997). Plague is caused by the bacillus Yersinia pestis that circulate mainly in rodent hosts and are transmitted between them and to other mammals via adult human and animal fleas, and predation or cannibalism, but potentially also by contaminated soil (Gage \& Kosoy, 2005; Drancourt et al., 2006). The disease is enzootic in a variety of wild rodent species and in diverse habitats (Stenseth et al., 2008). In Tanzania, plague is endemic in Lushoto district and cases generally occur in seasonal pulses (Kilonzo et al., 1997). Owing to focal nature of plague, environmental factors are suspected to play a role in the complex plague cycle and so may explain - at least partly - the details of its spatial distribution (Neerinckx et al., 2008).

Studies have indicated that plague distributions are consistent with changing climates (Nakazawa et al., 2008). Climate influences all three components of plague lifecycle, which include the bacteria, vectors, and hosts and is a likely factor to explain some of plague's variability from small and regional to large scales (Neerincks et al., 2008). Climate has long been suspected to be a key factor in the alternation between quiescent and active periods of plague (Rogers, 1928; Davis et al., 2006; Ari et al., 2011). It has been reported that human plague outbreaks in several African countries are less frequent when the weather is too hot $\left(>27^{\circ} \mathrm{C}\right)$ or cold $\left(<15^{\circ} \mathrm{C}\right)$ while an increased plague incidence during the hot, dry season, followed by a period of high seasonal rainfall has been reported in Vietnam (Pham et al., 2009). 
The plague system is the result of complex interactions between its components, the densities, life cycle, dynamics and geographical distributions, all of which are individually influenced by climate variables (Ari et al., 2011). Climate variables influence the dynamics of flea vectors and rodent hosts (Pham et al., 2009). The abundance of rodent fleas is affected by ambient temperature, rainfall, and relative humidity, with warm-moist weather providing a likely explanation for higher flea indices (Olson, 1969). It has been established that ambient temperature, rainfall, and relative humidity have direct effects on development and survival, as well as the behavior and reproduction of fleas and their populations. Rodent survival and population dynamics are also affected by climate. Moreover, a direct effect occurs when high intensity rainfall causes flooding of rodent burrows. Indeed, rainfall controls primary production which limits rodent abundances. Studies in Tanzania have shown that rodent population densities show clear association with annual rainfall and its seasonal distribution in Tanzania (Davis et al., 2006). In a study of the incidence of human plague in New Mexico in relation to precipitation, the number of human plague cases was positively associated with higher-than-normal winter-spring precipitation, perhaps because the wetter conditions favored rodent breeding (Permenter et al., 1999).

\section{Water-borne diseases}

Water-borne viral and bacterial infections can cause severe diarrhoea in children, often locking them into a vicious cycle of undernourishment, susceptibility to other infectious diseases, and eventually death. In countries with inadequate water and sanitation services, diarrhoea is much more common when temperatures are high (WHO, 2009). Both flooding and unusually low levels of water can also lead to water contamination and bring higher rates of illness and death from cholera and other diarrhoeal diseases (Hashizume, 2008). Warming and greater variability in rainfall threaten to increase the burden of these diseases. Warmer surface temperatures increase the abundance of phytoplankton, which supports a large population of zooplankton, which serves as a reservoir for cholera bacteria.

The combination of higher temperatures, prolonged droughts and floods coupled with scarce water resources and poor sanitation make Tanzania vulnerable to outbreaks of cholera and other waterborne diarrhoeal diseases. A study has already shown that during the 1997-98 El Niño, a rise in sea surface temperature coupled with excessive flooding emerged as two significant factors in cholera epidemics in Djibouti, Somalia, Kenya, Tanzania, and Mozambique. Another study in Lake Victoria basin has shown that the incidences of high cholera epidemics coincided with high flow peaks and high temperatures before and during El Niño years (Wandiga et al., 2006). Nonetheless, analysis of annual cholera trends indicates an irregular cyclical pattern; with general increase in cases and a reduction in interval between peaks. Recent analysis has shown that the five coastal regions in Tanzania are among the top-eight regions by number of cases per capita (Taylor, 2009). For a number of years, heavy rainfall in Dar es Salaam has been followed by cholera outbreaks, especially in areas of relatively low water table (Mayala et al., 2003). Flooded areas and ditches, latrines and septic tanks are key reservoirs that perpetuate cholera in Dar es Salaam. Community-based studies have also indicated an increase in awareness of climate-associated diseases in humans. Kangalawe (2012) observed in Mbeya Region that diarrhoeal diseases and respiratory infections were the most frequently climate-related diseases among the community.

\section{Impact of Climate Change on Health Systems}

Climate change is emerging as a major threat to health and adding pressure on public health systems. Climate change will affect, in profoundly adverse ways, some of the most fundamental prerequisites for good health: clean air and water, sufficient food, adequate shelter and freedom from diseases (WHO, 2009). Most often, extra pressure is placed on health care services by increased demands resulting from weather-related natural hazards such as floods and land-slides. Disruptions 
of social networks are not uncommon. Electric power outages can occur as a result of extreme weather-related events, which can affect the ability to communicate and carry out some operations during emergencies. There is interference with livelihoods such that people experience stress if their livelihoods and productivity are threatened. Severe weather events often result in loss of income and productivity, relocation of people, increased stress for families, and higher costs for health care and social services.

Most often, all infrastructures are designed for a specific climate, such as those related to food production, water management, energy production, drainage and sanitation systems, and housing and health infrastructures. Health risks may arise when any one of these systems fails or becomes compromised - as they may in a changing climate. For instance, limited access to water, electricity and sanitation could increase vulnerability to outbreaks of waterborne diseases including cholera (Shongwe, 2009). Climate change can increase the number of extreme weather events which can damage buildings, roads, and other infrastructure. This causes trauma to people including relocation to new places, as occurred following the recent rains in Kilosa and Dar es Salaam. This causes trauma to people including forced relocation to new places,

Since climate change is associated with more extreme precipitation events and rising sealevels, cities will also experience more severe and more frequent flooding (Ramin, 2009). Urbanization creates flood-prone conditions by covering the ground with pavement and buildings, and by building urban drains, causing runoff water to move more rapidly into rivers than under natural conditions (Douglas et al., 2008). The urban poor build houses of weak, inadequate materials, often against hillsides that are subject to landslides during heavy rains (Unger \& Riley, 2007). Climate change can result in damage to sanitation infrastructure resulting in the spread of disease or threatening a community's ability to maintain its economy, geographic location, or cultural-tradition leading to mental stress.

\section{Climate Change and Other Health-Related Problems}

Climate change can adversely impact the availability of water supplies, the efficiency of local sewerage systems, and food security (Schmidhuber \& Tubiello, 2007). Increased intensity and frequency of drought and flooding, altered hydrological cycles and precipitation variance have implications for future food security. In developing countries, growing population and loss of production due to climate change are expected contribute to increased food prices (FAO, 2007I). Already, higher temperatures, declining rainfall and water scarcity and floods in Tanzania are impacting negatively on food production resulting in food insecurity. Decreased agricultural productivity in the coming years could lead to food insecurity, hunger and famine in some communities severely affected by climate change. In Tanzania, agricultural production is mostly weather dependent, and has occasionally subjected the country to food shortage and insecurity in years with low rainfall (Kangalawe, 2012). Food security varies spatially and temporally depending on rainfall patterns and other multiple stress factors such as soil conditions, types of crops grown, socioeconomic and cultural factors. Food insecurity would in turn increase illness and death of vulnerable groups including women and children (Shongwe, 2009).

Climate change may affect health outcomes and food utilisation with additional malnutrition consequences. Populations in water-scarce regions are likely to face decreased water availability, with implications for the consumption of safe food and drinking water. Both acute and chronic nutritional problems are associated with climate change. The effects of drought on health include deaths, malnutrition (undernutrition, protein-energy malnutrition and/or micronutrient deficiencies), infectious diseases and respiratory diseases. Drought diminishes dietary diversity and reduces overall food consumption, and may therefore lead to micronutrient deficiencies. Malnutrition increases the risk both of acquiring and of dying from an infectious disease. Drought and the consequent loss of livelihoods is also a major trigger for population movements. Population displacement can lead to 
increases in communicable diseases and poor nutritional status resulting from overcrowding, and a lack of safe water, food and shelter (del Ninno \& Lundberg, 2005).

Most of the climate change impacts in Africa are associated with rainfall variability and scarcity of water resources. Water scarcity is already a major problem for the world's poor. The number of people impacted by water scarcity is projected to increase from about 1.7 billion people about ten years ago to around 5 billion people by 2025, independent of climate change (IPCC, 2001). Climate change is projected to further reduce water availability in many water scarce regions, particularly, subtropics, due to increased frequency of droughts, increased evaporation, and changes in rainfall patterns and run-off. Climate change-induced droughts, flooding and other extreme weather events degrade and reduce portable water supplies and increases water-associated diarrhoeal diseases, particularly in areas with inadequate sanitary infrastructures. Almost $90 \%$ of the burden of diarrhoeal disease is attributable to lack of access to safe water, sanitation (WDR, 2010; Prüss-Üstüm et al., 2008) and reductions in the availability and reliability of freshwater supplies are expected to amplify this hazard. On the other hand, droughts have a direct impact on health, particularly in children. It has been established that underfives born during drought years are more likely to be undernourished and stunted (Speranza et al. 2008)

Population displacement associated with natural hazards compromises health and damages lives. By destroying ecological and agricultural systems and by flooding communities, climate change can eventually force people to abandon where they live in order to seek new homes and livelihoods. Forced displacement is associated with a range of health issues, including social isolation and mental disorders, and in many cases, reduced socio-economic status and associated health problems.

\section{Climate change vulnerability and adaptation in Tanzania}

Vulnerability, poverty and disease are tangled in a complex set of socio-economic and environmental conditions that can create heightened susceptibility to illness among certain individuals within a community. Understanding the determinants of health is fundamental to understanding how communities and individuals adapt to avoid risk and illness. Vulnerability is also tightly linked to inequity with respect to access to resources, decision-making power and capacity to cope. The continued prevalence of illness and vulnerability stems itself in part in the continued inequality within and between households, communities and countries. Inequality affects vulnerability directly by constraining the options available to communities, households and individuals when faced with external shocks, and indirectly through its various links to poverty. Factors such as the ability to mitigate increased vulnerability associated with illness, access to timely diagnosis and care, and access to adequate nutrition all play a role in managing vulnerability and disease progression.

For many communities, adaptation to climate change has been a survival strategy that has been well-refined over time. Increasing variability and frequency of unusual weather events places the livelihoods of those most vulnerable to climate change at risk by testing their ability to adapt. Innovation, knowledge and coping strategies often exist within the fabric of social structures at the community level (Yamin et al., 2005). The impacts of climate change and the vulnerability of poor communities to climate change vary greatly, but generally, climate change is superimposed on existing vulnerabilities. In some areas where livelihood choices are limited, decreasing crop and livestock yields threaten famines.

Although all populations will be affected by a changing climate, but the initial health risks vary greatly, depending on where and how people live. Health effects are expected to be more severe for elderly people and people with infirmities or pre-existing medical conditions (WHO, 2009). The groups who are likely to bear most of the resulting disease burden are children and the poor, especially women. Supporting community-led adaptation means putting communities' centre-stage in determining which vulnerabilities are addressed and how they are addressed. In order to 
understand the true implications of climate change on those most vulnerable, impacts must be viewed from within the context of their everyday lives.

Assessment of vulnerability and adaptation to climate change in various sectors in Tanzania form part of the Initial National Communication (INC). Currently, there are two disaster vulnerability assessment reports conducted in 2002 and 2003 which reveal the situation at the community level. Among the major causes of the vulnerability at village, district and national levels include epidemics, drought, pest/vermin/plant diseases and floods. Through the National Adaptation Programme of Action, various coping strategies have been identified.

There are a few documented reports on community adaptation to climate change in Tanzania. This is likely to contribute to the low knowledge of the community on what is climate change. In a study conducted in Mbeya Region, Kangalawe (2012) reported that the concept "climate change" was associated with variability in weather condition such as rainfall inconsistency and unpredictability over years. Increasing temperatures; shortened growing seasons; late coming of rains in the seasons; recurrent food shortage, rainfall coming too early and increased incidences of drought were reported by the local community as the major indicators of climate change. Interestingly, in a recent study carried out among farming communities in Kilosa district, only one in four respondents understood the official Kiswahili term for climate change "Mabadiliko ya Tabia Nchi", which is currently used by the government in circulated materials about climate change. Like in Mbeya, there was a general understanding among the Kilosa community that the rain patterns have changed in the past 10 years; however there were a range of descriptions for this change (Fahey et al., 2011). There was more agreement on temperature change, with $62 \%$ believing that the temperature has increased in the last 10 years (Fahey et al., 2011). The lack of comprehension of climate change shows that the community has not received education on climate change which could prepare them for possible consequences. There was a general awareness that the temperature was rising and the rains were changing, which may have attributed to some of the change in crop variety reported by the farmers. Such flexibility is important for resilience to climate change.

Traditional coping mechanisms at household and community levels are backward looking, based on historical experience and observation. In the face of changing patterns of climate variability and the significant deviations from historical experience, their effectiveness may be significantly reduced. The 1998 high rainfall due to El Nino was followed by a two-year period of erratic rainfall. This climatic shock caused some of the poorer farmers to give up maize farming and opt instead to sell their labour at farms in other more productive areas. The resulting dependence on physical working capacity as their sole endowment increased vulnerability, since malnutrition and disease can reduce their capacities for manual labour. Climate change many thus force drastic changes to livelihood strategies. Where economic diversification is low, income opportunities and hence option for developing alternative livelihoods in response to climatic changes may be limited. In some cases migration, which is an important coping strategy for poor people, might be the only solution, but will potentially cause social disruption.

Many adaptation mechanisms need to be strengthened by making progress in areas such as good governance, human resources, institutional structures, public finance, and natural resource management. Such progress builds the resilience of the country, communities, and households to all types of shocks, including climate change impacts. Strategies to cope with current climate variability should provide a good starting point for addressing adaptation needs in the context of poverty reduction. Progress will require improved governance, including an active civil society and open, transparent and accountable policy and decision making processes, which can have a critical bearing on the way in which policies and institutions respond to the impact on climatic factors on the poor. Adaptation efforts will require first steps towards mainstreaming climate issues into all national, regional, district and sectorial planning processes, such as poverty reduction strategies. It is equally important that a ministry with a broad mandate, such as finance and economic affairs is been encouraged to be fully involved in mainstreaming adaptation. There must be combined approaches 
at the government and institutional level with bottom-up approaches rooted in regional, national and local knowledge. Empowerment of communities is necessary so that they can participate in assessments and feed in their knowledge to provide useful climate change information. They will also need full access to climate relevant information systems. Access to good quality information about the impacts of climate change is important. Early warning systems and information distribution systems held to anticipate and prevent disasters.

An approach that uses both mitigation and adaptation is needed. Current commitment to mitigate climate change by limiting the emission of greenhouse gases will not, even if implemented, stabilize the atmospheric concentrations of these gases. Developing adaptive capacity to minimize the damage to livelihoods from climate change is a necessary strategy to complement climate change mitigation efforts. Climate change adaptation i.e. all those responses to climatic conditions that reduce vulnerability, should therefore be an integral and urgent part of overall poverty reduction strategies. Adaptation should not be approached as a separate activity, isolated from other environmental and socio-economic concerns that also impact on the development opportunities to the poor. A comprehensive approach is needed that takes into account potential synergistic and antagonistic effects between local and global environmental changes as well as socioeconomic factors.

\section{Climate Change Related Policies in Tanzania}

\section{Policy frameworks}

There is no single policy document that is solely responsible for climate change in Tanzania. The National Environmental Management Policy of 1997 recognizes the importance of climate change. It calls for responsible ministries to put up measures to address climate change. The Minister responsible for environment is also mandated to issue guidelines in order to address climate change and its impacts. Although the Policy has been in place for 14 years now, still the guidelines are yet to be developed. On the other hand, the Environmental Management Act of 2004 provides legal and institutional framework for sustainable management of environment in Tanzania. It outlines principle for management, impact and risk assessments, prevention and control of pollution, waste management, environmental quality standards, public participation, compliance and enforcement; provides basis for implementation of international instruments on environment; and provides legal framework for implementation of the National Environment Policy (URT, 2005).

Recognizing the adverse impacts of natural disasters and calamities to the socio-economy of the country, the government established a Department of Disaster Management under the Prime Minister's Office. Moreover, recently, a National Adaptation Programme of Action (NAPA) has been developed. NAPA is linked with other national development policies, goals, objectives, plans, strategies and programmes and supports/complements strategies and programmes of other multilateral environmental agreement that Tanzania is engaged. These include the United Nations Convention to Combat Desertification (UNCCD), United Nations Framework Convention on Climate Change (UNFCCC), the Convention on Biological Diversity (CBD), Basel Convention on the Control of Transboundary Movements of Hazardous Wastes and their Disposal, Vienna Convention on the Protection of Ozone Layer and Montreal Protocol on Substances that Deplete the Ozone Layer. A number of strategies and action plans related to some of these conventions are in place (NAPA, 2007). These include the National Biodiversity Strategy and Action Plan (NBSAP), the National Action Programme (NAP), and the National Biosafety Framework (NBF). The National Environmental Policy (NEP) of 1997 provides a framework for mainstreaming environmental considerations into the decision making process in Tanzania. Though NEP does not pay explicit attention to climate change, the primary environmental issues brought forward include many of the concerns that would be addressed by non-regrets climate change adaptation measures. NEP highlights the importance of integrating environmental management in several sectoral programmes and policies. 
The National Forest Policy (NFP) of 1998 is another climate change related policy. One of the objectives of the NFP is to ensure ecosystems stability through conservation of forest biodiversity, water catchments, and soil fertility. The policy states that new forest reserve for conservation will be established in areas of high biodiversity value and that biodiversity conservation and management will be included in the management of plans for all protected forests. On the other hand, the Reducing Emissions from Deforestation and Forest Degradation (REDD) initiative is among the recent efforts envisaged to play a significant role in climate change mitigation and adaptation (REDD, 2009). The legal framework in support of environmental management in Tanzania promote sustainable forest management and protection which are important for the implementation of REDD policy.

\section{Coordination and Management of Climate-related Disasters}

In accordance with the Environmental Management Act of 2004, all environmental management issues inter alia climate change are coordinated by the Vice President's Office. In line with this Act, the functions of the Division of Environment mandate the Division to coordinate all climate change issues including adaptation and mitigation. The government has put in place a National Climate Change Steering Committee (NCCS) and the National Climate Change Technical Committee to oversee and guide the implementation of climate change activities in the country. However, information on how much the NCCS has prepared the country to mitigate climate change impacts on health and health systems is not available.

Several Acts and Ordinances govern the management of disasters in Tanzania. Among them is the Disaster Management Act No. 9 of 1990 (URT, 1991; 2002). This Act derives its power from the Constitution of the United Republic of Tanzania of 1977. The Constitution empowers the President to proclaim a state of emergency if there is imminent occurrence of dangerous disaster, which threatens the communities or part thereof in the United Republic of Tanzania. Correspondingly, at the regional and district levels, the respective Regional and District Commissioner, is the appropriate authority to declare a regional/district disaster situation.

Disaster management requires an integrated multi-sectoral approach, which provides for a comprehensive and active participation and interaction of all key players. The Tanzania Disaster Relief Coordination Committee (TANDREC) is the established body responsible for disaster management in the country. The TANDREC is the body that has been assigned leadership and coordinating responsibilities for the nation's disaster management system. Its job is to lead the country in developing and maintaining a national disaster preparedness and management system that helps people to protect themselves, their families, property and environment from all disasters.

The Disaster Management Department is the Central Government Agency specifically created as a Secretariat to the TANDREC to coordinate and supervise disaster management activities in the country. Disaster problems addressed in Tanzania include: (i) disease epidemics; (ii) drought leading to famine; (iii) vermin, pest infestation and animal diseases; (iv) transport accidents; (v) conflicts; (vi) floods; (vii) fires; (viii) earthquakes; and (ix) landslides (URT, 1991).

In recognition of the public health importance and the implications of emergencies and disasters to the well being of the society, the Government of Tanzania, through the Ministry of Health and Social Welfare, has established a functional unit of emergency preparedness and response to address all health aspects of emergencies and disasters in the country. This unit, which is under the Chief Medical Officer's office, is called the Emergency Preparedness and Response Unit (EPRU). Among other many functions, the Unit is responsible to collaborate with other departments in the Ministry of Health and Social Welfare in controlling major epidemics and other health emergencies and disasters.

Epidemic preparedness includes measures taken to enhance the abilities of individuals, communities, districts and the nation to respond to disease outbreaks. Epidemic preparedness is one of outbreak management's fundamental tasks, since prevention and mitigation actions cannot 
completely eliminate epidemics. Preparedness activities are directed towards facilitating emergency response, thus reinforcing mitigation or outbreak containment measures (URT, 1991; 2002; MoH, 2004). Emergency Preparedness is one of the Strategic Objective of the current Health Sector Strategic Plan III, 2009-2015 (MoHSW, 2008). In addition to the Disaster Management Act, several others legal documents are important in the management of disease epidemics. These include: (i) Infectious Disease Ordinance Cap 96; (ii) Public Health (Sewerage and Drainage) Ordinance Cap 336; (iii) Local Government (Urban Authorities) Act, 1982; (iv) Local Government (District Authorities) (Miscellaneous Amendments) Act, 1999; (vi) Public Health Act (2009).

A review of the government policy document has shown that in Tanzania climate change impacts on health have received very little attention both in terms of research and strategic implementation. At least the Goal 4 of the current National Strategy for Growth and Reduction of Poverty II (NSGRP, 2010) aims to ensuring food security and adapting and mitigating effects of climate change. However, to remain focussed, climate change will emphasize food insecurity. In this case, the $\mathrm{CC}$ interventions will be those that address: (i) food security at household, district, regional, and national levels; (ii) crop and livestock varieties suited to adverse conditions brought about by climate change. In the current National Health Research Priorities (2006-2011), climate change does not appear to be priority research area (NIMR, 2006). Although, the National Institute for Medical Research Strategic Plan Objective 2.6 (Research on Ecosystems and Environmental Health) states the need to "Conduct of studies on climate change" (NIMR, 2008) to our knowledge only three such studies have been carried out in Tanzania during the period of 2008-2011.

\section{Conclusion and the way forward}

In summary, there are number of potential impacts of climate change on the national development goals. Climate change is projected to reduce poor people's livelihood assets, health, access to water, homes, and infrastructure. Climate change is expected to alter the path and rate of economic growth due to changes in natural systems and resources, infrastructure, and labour productivity. Indirectly, loss of livelihood assets may reduce opportunities for full-time education and accessibility to health in numerous ways. Climate change is expected to exacerbate current gender inequalities in the sense that depletion of natural resources and decreasing agricultural productivity may place additional burdens on women's health and reduce time available to participate in decision making processes and income generating activities. Climate change may increase the geographical distribution and prevalence of vector- and water-borne diseases. These changes in disease prevalence and incidence are likely to mediated through biological, ecological, sociologica, and epidemiologic processes that interact with each other and which may themselves be influenced by climate change (Chan et al., 1999). Climate change will likely result in declining quality and quantity of drinking water, which is a prerequisite for good health, and exacerbate malnutrition by reducing natural resource productivity and threatening food security.

There is now a consensus that the earth is warming due to emissions of greenhouse gases caused by human activities. The current trends in energy use, development and population growth will lead to continuing and more severe climate change. Societies have adapted to past changes in climate, although some with much more difficult than others. Enhanced capacity to adapt to the impacts of climate change on health can reduce the associated threats to human health and wellbeing. By generating and acquiring new knowledge or synthesizing existing knowledge on anticipated future climate change risks and their possible consequences, responses to these stresses can be faster, more efficient and effective. Better organizing institutions, processes and actions around present and anticipated health challenges across sectors and levels of decision-making can also help with preparedness. Ultimately, societies should be able to avoid, prepare for, and effectively respond to health impacts related to climate change. In addition, assessing possible climate impacts could be an opportunity for institutions and policy-makers to discuss how to do 
better development; to build individual, community and institutional capacity; and to improve response to certain health and environmental problems. The development and documentation of cases of adaptation to climate related health challenges, would be an important contribution to ongoing efforts in Tanzania.

The changes in climate happen gradually and if prompt actions are taken timely, there is time to learn more about the epidemiology and ecology of the climate related diseases. There will also be time to devise better control and prevention strategies. All these require investment in research. Tanzania should aim to devise better direct intervention measures for these diseases. However, we also need more information about vector agents, modes of transmission, reservoirs, and the effect of temperature, rainfall, and other climate-related parameters on the vectors, vertebrate hosts, and the agents of disease themselves. Studies of ecology of the disease agents and their reservoirs would be especially valuable. Such information could be used to predict more accurately which of the diseases to target as threats, and which will be less likely to spread and/or become more severe. Attribution to current and future climate change related disease burdens is a challenge because the determinants of diseases are complex. The magnitude and factors affecting climate change related diseases among communities in Tanzania need to be better quantified. Research and information on the links between climate-change related diseases are therefore, necessary.

Weather and climate forecasts and early warnings systems needs to be developed and implemented. Such systems can be used to provide information that enables and persuades people and organizations to protect themselves and their property, and thereby reduces the deaths, injury and damage caused by the hazards. However, in the long run, the greatest health impacts of climate change may not be from acute shocks of epidemics or natural disasters, but from the gradual buildup of pressure on the natural and socio-economic systems that sustain health, and which are already constrained by HIV/AIDS, malaria and tuberculosis.

It is only when the climate change issues are addressed adequately that Tanzania would be able to make headway in the achievements of the development goals, including those contained in the National Strategy for Growth and Reduction of Poverty (NSGRP) II; Development Vision 2005; and Millennium Development Goals (MDG). MDG Number 6 and 7 deal with HIV/AIDS, Malaria and other diseases; and ensure Environmental Sustainability, respectively. These are among the MDGs that are directly related to food, health and climate. Climate change challenges the achievement of the MDGs and NSGRP and sustainable development objectives. Unless concrete and urgent steps are undertaken to reduce vulnerability and enhance adaptive capacity of poor people, and unless these actions are integrated in national strategies for poverty eradication and sustainable development, it may be difficult to meet some MDGs by 2015 .

Through the contribution of modern meteorological and hydrological sciences and technology it is possible to provide communities threatened by potential climate disasters with information to instigate timely preventive action. Governmental organizations, the media, nongovernmental organizations and other key stakeholders need to create effective preparedness plans, warning systems, mitigation strategies and public education programmes. Local capacity building for basic and applied research is essential to allow regular assessment of diseases, particularly the ecological, social and economic determinants of diseases.

A key initiative across all issues is community education. The farmers and the general community need to be prepared with news about climate change and possible adaptations in order to ensure food security and unusual health events in coming years. There is a need to raise community awareness of links between climate change and health.

It is important that government initiate and strengthen programmes to raise awareness of potential health impacts of climate change and action needed to reduce likelihood of adverse health outcomes to all key stakeholders including the communities. The government should bring together stakeholders with a role in the climate change agenda to discuss and agree on a common strategy to address climate change and its impact on socio-economic development. Through these strategies, it 
is envisaged that the Tanzania population will have increased knowledge of potential health impacts of climate change; will be more aware of how climate change impacts on different groups within the population; will be able to identify key groups including professionals, politicians, policy makers and community groups who have roles to play in reducing likelihood of adverse health outcomes from climate change and will ultimately, be more aware of what action is needed to reduce likelihood of adverse health outcomes.

Although the impact of climate change on health and health systems have been documented in Tanzania, there have not yet been thorough quantitative studies addressing the many processes at work. This is most likely to be because of the complexity of the many interactions or mechanisms that bear on all aspects of the climate change issue. It is therefore important that the government develops a national framework for an integrated assessment of the impacts of climate change on human health. Such a framework will allow identification of potentially important indirect interactions or mechanisms, identification of important research gaps, and a means of integrating targeted research from a variety of disciplines into an enhanced understanding of the whole system.

\section{Acknowledgements}

We are grateful to Drs. Esron Karimuribo and Calvin Sindato for their critical review of the earlier draft of the manuscript.

\section{References}

Afrane, Y.A., Zhou, G., Lawson, B.W., Githeko, A.K., Yan, G. (2006) Effects of microclimatic changes caused by deforestation on the survivorship and reproductive fitness of Anopheles gambiae In Western Kenya Highlands. American Journal of Tropical Medicine and Hygiene 74, 772-778.

Ari, T.B., Neerinckx, S., Gage,K.L., Kreppel, K., Laudisoit, A., Leirs, H. \& Stenseth, N.C. (2011) Plague and Climate: Scales Matter. PLoS Pathogens 7 (9): 7(9): e1002160.

Biggs, H.M., Bui, D.M., Galloway, R.L., Stoddard, R.A., Shadomy, S.V., Morrissey, A.B., Bartlett, J.A., Onyango, J.J., Maro, V.P., Kinabo, G.D., Saganda, W. \& Crump, J.A. (2011) Leptospirosis among hospitalized febrile patients in northern Tanzania. American Journal of Tropical Medicine and Hygiene 88, 275-281.

Bødker, R., Akida, J., Shayo, D., Kisinza, W., Msangeni, H. A., Pedersen, E.M. \& Lindsay, S.W. (2003). Relationship between altitude and intensity of malaria transmission in the Usambara Mountains, Tanzania. Journal of Medical Entomology 40, 706-717.

Bødker, R., Msangeni, H.A., Kisinza, W.N. \& Lindsay, S.W. (2006) Relationship between the intensity of exposure to malaria parasites and infection in the Usambara Mountains Tanzania. American Journal of Tropical Medicine and Hygiene 74, 716-723.

Brooker, S., Issae, W., Hall1, A., Kihamia, C.M., Lwambo, N.J.S., Hay, S.I., Wint, W., Rogers, D.J. \& Bundy, D.A.P. (2001) Predicting the distribution of urinary schistosomiasis in Tanzania using satellite sensor data. Tropical Medicine and international Health 6 (10), 1-10.

Chan, N.Y., Ebi, K.L., Smith, F., Wilson, T.F. \& Smith, A.E. (1999) An integrated assessment framework for climate change and infectious diseases. Environmental Health Perspectives 107, 329-337.

Chivian, E. \& Bernstein, A.S. (2004) Embedded in nature: human health and biodiversity. Environmental Health Perspective 112, A12-A13.

Clyde, D.F. (1967) Malaria in Tanzania. Oxford University Press.

Coluzzi, M., Sabatini, A., Petrarca, V. \& Di Deco, M.A. (1979) Chromosomal differentiation and adaptation to human environment in the Anopheles gambiae complex. Transactions of the Royal Society of Medicine and Hygiene 73, 483-497.

Courtin, F., Jamonneau, V., Duvallet, G., Garcia, A., Coulibaly, B., Doumenge, J.P., Cuny, G. \& Solano, P. (2008) Sleeping sickness in West Africa (1906-2006): changes in spatial 
repartition and lessons from the past. Tropical Medicine and International Health 13,334344.

Crabtree M, Sang R, Lutomiah J, Richardson J, Miller B. (2007) Arbovirus surveillance of mosquitoes collected at sites of active Rift Valley Fever Virus Transmission: Kenya 2006-2007. Journal of Medical Entomology 46, 961-964.

del Ninno, C. \& Lundberg, M. (2005) Treading water: the long term impact of the 1998 flood on nutrition in Bangladesh. Economics \& Human Biology 3, 67-96.

Douglas, I., Alam, K., Maghenda, M., McDonnell, Y., Mclean, L., Campbell, J. (2008) Unjust waters: climate change, flooding and the urban poor in Africa. Environment and Urbanization 20, 187205.

Drancourt, M., Houhamdi, L., Raoult, D. (2006) Yersinia pestis as a telluric, human ectoparasiteborne organism. Lancet Infectious Diseases 6:234-241.

Ebi, K., Woodruff, R., Hildebrand, A. \& Corvalan, C. (2007) Climate change related health impacts in the Hindu Kush-Himalayas. EcoHealth 4, no. 3: 264 - 270.

Fahey, C., Wei, D., Bwana, V., Mlacha, T., Stanley, G., Senkoro, K.P., Mboera, L.E.G. (2011) Integrating Agriculture, Food Security, and Malaria in Tanzania. National Institute for Medical Research Headquarters Quarterly Report (October-December 2011).

FAO (2007) Adaptation to climate change in agriculture, forestry and fisheries: Perspective, frameworks and priorities. FAO, Rome.

Fukumi, H., Hayashi, K., Mifune, K., Ujiiye, A., Suenaga, O., Futatsuki, K., Matsuo, S. \& Miyagi, I. (1967) Epidemiological studies on viral and parasitic diseases, and vector insects in East Africa: I. Virological studies especially on the epidemiology of Arboviruses (Preliminary Report). Tropical Medicine 9, 127-135.

Gage, K.L. \& Kosoy, M.Y. (2005) Natural history of plague: perspectives from more than a century of research. Annual Review of Entomology 50, 505-528.

Garay, J. (1998) Epidemiological survey and situation analysis: Malaria epidemic in Nshamba Division, Muleba District, Tanzania. 47 pp. MSF Spain.

Gillies, M.T. (1953) The duration of the gonotrophic cycle in Anopheles gambiae and An. funestus with a note on the efficiency of hand catching. East African Medical Journal 30: 129-135.

Githeko, A.K., Lindsay, S.W., Confalonieri, U.E. \& Patz, J.A. (2000) Climate change and vector-borne diseases: a regional analysis. Bulletin of the World Health Organization 78, 1136-1147.

Gubler, D.J. \& Clark, C.G. (1995) Dengue/Dengue hemorrhagic fever: The emergence of a global health problem. Emerging Infectious Diseases 1: 55-57

Gubler, D.J. (2000) Epidemic dengue/dengue hemorrhagic fever as a public health, social, and economic problem in the $21^{\text {st }}$ century. Trends in Microbiology 10,100-103.

Gubler, D.J., Sather, G.E., Kuno, G. \& Cabral, J.R. (1986) Dengue 3 virus transmission in Africa. American Journal of Tropical Medicine and Hygiene35, 1280-1284.

Hales, S., de Wet, N., Maindonald, J. \& Woodward, A. (2002) Potential effect of population and climate changes on global distribution of dengue fever: an empirical model. Lancet 360:830834.

Harrus, S. \& Baneth, G. (2005) Drivers for the emergence and re-emergence of vector-borne protozoal and bacterial diseases. International Journal Parasitology 35, 1309-1318.

Hashizume, M. (2008) The effect of rainfall on the incidence of cholera in Bangladesh. Epidemiology $19,103-110$.

Hertz, J.T., Munishi, O.M., Ooi, E., Howe, S., Lim, S.Y., Chow, A., Morrissey, A.B., Bartlett, J.A., Onyango, J.J., Maro, V.P., Kinabo, G.D., Saganda, U., Gubler, D.J. \& Crump, J.A. (2012) Chikungunya and Dengue fever among hospitalized febrile patients in northern Tanzania. American Journal of Tropical Medicine and Hygiene 86, 171-177.

Hightower, A., Kinkade, C., Nguku, P.M., Anyangu, A., Mutonga, D.,Omolo, J., Njenga, M.K., Feikin, D.R., Schanbel, D., Ombok, M. \& Breiman, R.F. (2012) Relationship of Climate, Geography, and 
Geology to the Incidence of Rift Valley Fever in Kenya during the 2006-2007 Outbreak. American Journal of Tropical Medicine and Hygiene 86, 373-380.

lijima, T. \& Sugiura, S. (1962) Studies on the temperature as a limiting factor for the survival of Oncomelania nosophora, the vector snail of Schistosoma japonicum in Japan. Japanese Journal Medical Science and Biology 15:221-228

IPCC (2001) Intergovernmental Panel on Climate Change (IPCC) 2001. Climate Change 2001: Impacts, Adaptation, and Vulnerability. Cambridge. Cambridge University Press.

IPCC (2007) Climate Change 2007: Impacts Adaptation and Vulnerability. Contributions of Working Group II to the Fourth Assessment Report of the Intergovernmental Pannel on Climate Change, Cambridge, UK: Cambridge University Press.

Jetten, T.H. \& Focks, D.A. (1997) Potential changes in the distribution of dengue transmission under climate warming. American Journal of Tropical Medicine and Hygiene 57, 285-297.

Jones, A.E., Wort, U.U., Morse, A.P., Hastings, I.M. \& Gagnon, A.S. (2007) Climate prediction of El Nino malaria epidemics in north-west Tanzania. Malaria Journal 6: 162.

Kandji, S.T. \& Verchot, L.V. (2005) Impacts of and Adaptation to Climate Variability and Climate Change in the East African Community. A focus on the Agricultural Sector. World Agroforestry Centre.

Kangalawe, R.Y.M. (2009) Impact of climate change on human health: Example of highland malaria Mbeya Region. Study report submitted to the Division of Environment, Vice President's Office, Dar es Salaam, Tanzania.

Kangalawe, R.Y.M. (2012) Food security and health in the southern highlands of Tanzania: A multidisciplinary approach to evaluate the impact of climate change and other stress factors. African Journal of Environmental Science and Technology 6, 50 -66.doi: 10.5897/ajest11.003

Kilonzo, B.S., Mvena, Z.S., Machangu, R.S. \& Mbise, T.J. (1997) Preliminary observations on factors responsible for long persistence and continued outbreaks of plague in Lushoto district, Tanzania. Acta Tropica 68, 215-227.

Kokernot RH, Smithburn KC, Weinbren MP. Neutralising antibodies to arthropod-borne viruses in human and animals in the Union of South Africa. J Immunol 77: 313-322.

Kokernot RH, Smithburn KC, Weinbren MP. Neutralising antibodies to arthropod-borne viruses in human and animals in the Union of South Africa. J Immunol 77: 313-322.

Leopoldo M. Rueda (2004) "Pictorial Keys for the Identification of mosquitoes (Diptera: Culicidae) associated with dengue virus transmission" Magnolia Press, Auckland, New Zealand.

Lindsay, S.W. \& Birley, M.H. (1996) Climate change and malaria transmission. Annals of Tropical Medicine and Parasitology 90: 573-588.

Lindsay, S.W. \& Martens, W.J. (1998) Malaria in the African highlands: past, present and future. Bulletin of the World Health Organization 76: 33-45.

Lindsay, S.W., Bødker, R., Malima, R., Msangeni, H. A. And Kisinza, W. (2000) Effect of 1997-8 El Niño on highland malaria in Tanzania. Lancet 355, 989-990.

Lutwama, J.J., Rwaguma, E.B., Nawanga, P.L., Mukuya, A. (2002) Isolations of Bwamba virus from south central Uganda and north eastern Tanzania. African Health Science 2(1): 24-28.

Lutwama, J.J., Rwaguma, E.B., Nawanga, P.L., Mukuya, A. (2002) Isolations of Bwamba virus from south central Uganda and north eastern Tanzania. African Health Science 2(1): 24-28.

Lwambo N.J.S. (2005) Schistosomiasis and Soil-Transmitted Helminthiasis in Tanzania, Tanzania health Research Bulletin 7, iii - iv

Lwambo, N.J.S. Siza, J.E., Brooker, S., Bundy, D.A.P. \& Guyat, H.(1999) Patterns of concurrent hookworm infection and schistosomiasis in schoolchildren in Tanzania. Transactions of the Royal Society of Tropical Medicine and Hygiene 93 497-505

Lwambo, N.J.S., Siza, J.E., Brooker, S., Bundy, D.A.P., Guyyat, H. (1999) Patterns of concurrent hookworms infection and schistosomiasis in school children in Tanzania. Transaction of Royal Society of Tropical Medicine and Hygiene 93 497-502. 
Machang'u, R. S., Mgode, G., Asenga, J., Mhamphi, G., Hartskeerl, R., Goris, M., Cox, C., Weetjens, B. \& Verhagen, R. (2003) Characterization of Leptospira isolates from captive giant pouched rats, Cricetomys gambianus. In Rats, Mice and People, Rodent Biology and Management, pp. 4042. Edited by G. R. Singleton, L. A. Hinds, C. J. Krebs \& M. D. Spratt. Canberra: Australian Centre for International Agricultural Research.

Machang'u, R.S., Mgode, G. \& Mpanduji, D. (1997) Leptospirosis in animals and humans in selected areas of Tanzania. Belgium Journal of Zoology 127, 97-104.

Marti, H.P., Tanner, M., Degremont, A.A. \& Freyvogel, T.A. (1985) Studies on the ecology of Bulinus globosus, the intermediate host of Schistosoma haematobium in the Ifakara area, Tanzania. Acta Tropica 42, 171-187.

Matola, Y.G., White, G.B. \& Magayuka, S.A. (1987). The changed pattern of malaria endemicity and transmission at Amani in the eastern Usambara mountains, north-eastern Tanzania. Journal of Tropical Medicine and Hygiene, 90, 127-134.

Mayala, B.K., Mboera, L.E.G. \& Gwacha, F. (2003) Mapping cholera risks using Geographical Information System in Ilala District, Tanzania. Tanzania Health Research Bulletin 5, 8-12.

Mboera, L.E.G. \& Kitua, A.Y. (2001) Malaria epidemics in Tanzania: An overview. African Journal of Health Sciences 8, 14-18.

Mboera, L.E.G. (2004) Environmental and socio-economic determinants of malaria epidemics in the highlands of Tanzania, Tanzania Health Research Bulletin 6, 11-17.

Mboera, L.E.G., Kamugisha, M.L., Njunwa, K.J., Mutalemwa, P., Kitua, A.Y., Salum, F.M. \& Makunde, W.H. (1999) Study on epidemiological factors related to malaria epidemics in Babati, Dodoma and Lushoto districts of Tanzania. Report of the Project ID 001/98 submitted to the National Institute for Medical Research.

Mboera, L.E.G., Massaga, J.J., Munga, M.A., Mayala, B.K., Kahwa, A.M., Msovela, J.,Shija, A., Mushi, A.K. \& Kilale, A.M. (2010) Current status of the service availability at various levels Health System in Tanzania. National Institute for Medical Research, Dar es Salaam, Tanzania.

Mboera, L.E.G., Molteni, F., Nyange, A. \& Thomas, E.G. (2005) Using retrospective epidemiological data to determine malaria epidemic prone areas and development of an epidemic early warning system in Mpwapwa District, central Tanzania. Tanzania Health Research Bulletin 7, 73-78.

McMichael, A.J., Haines, A., Slooff, R. \& Kovats, S. (1996) Climate Change and Human Health. Geneva: World Health Organisation.

Messer, W.B., Gubler, D.J., Harris, E., Sivananthan, K., De Silva, A.M. (2003) Emergence and global spread of dengue serotype 3, Subtype III virus. Emerg Infec Dis. 2003; 9(7):800-9.

Mgode, G.F., Machang'u, R.S., Gorsi, M.G., Engelbert, M., Sondij, S. \& Hartskeerl, R.A. (2006) New Leptospira serovar Sokoine of serogroup Icterohaemorrhagiae from cattle in Tanzania (2006) International Journal of Systematic and Evolutionary Microbiology 56, 593-597.

MoH (2004) Disease Outbreak Management: A Field Manual for Council Health Management Teams. Ministry of Health, United Republic of Tanzania. Version 1. February 2004.

Mohamed, M., Mosha, F., Mghamba, J., Zaki, S.R., Shieh, W-J., Paweska, J., Omulo, S., Gikundi, S., Mmbuji, P., Bloland, P., Zeidner,N., Kalinga, R., Breiman, R.F. \& Njenga, M.K. (2010) Epidemiologic and clinical aspects of a Rift Valley fever outbreak in humans in Tanzania, 2007. American Journal of Tropical Medicine and Hygiene 83, 22-27.

MoHSW (2008) Health Sector Strategic Plan III (2008-2015). Ministry of Health and Social Welfare, Dar es Salaam, United Republic of Tanzania.

Moore, S., Shresthna, S., Tomlinson, K.W. \& Vuong, H. (2011) Predicting the effect of climate change on African Trypanosomiasis: integrating epidemiology with parasite and vector biology. Journal of the Royal Society Interface. doi: 10.1098/rsif.2011.0654. 
Mutuku, F.M., King, C.H., Bustinduy, A.I., Mungai, P.I., Muchiri, E.M. \& Kitron, U. (2011) Impact of Drought on the Spatial Pattern of Transmission of S. haematobium in Coastal Kenya. American Journal of Tropical Medicine and Hygiene 85, $1065-1070$.

Mwandosya, M.J., Nyenzi, B.S. \& Luhanga, M.L. (1998) The Assessment of Vulnerability and Adaptation to Climate Change Impacts in Tanzania. Dar-es-Salaam, Tanzania: Centre for Energy, Environment, Science and Technology (CEEST).

Nakazawa, Y., Williams, R., Peterson, A.T., Mead, P., Staples, J.E., Gage, K. (2007) Climate change effects on plague and tularemia in the United States. Vector Borne Zoonotic Diseases 7, 529-540.

NAPA (2007) Tanzania: National Adaptation Plan for Action. United Republic of Tanzania.

Neerinckx, S.B., Peterson, A.T., Gulinck, H.,Deckers, J. \& Leirs,H. (2008) Geographic distribution and ecological niche of plague in sub-Saharan Africa. International Journal of Health Geographics 7:54

NIMR (2006) National Health Research Priorities. National Institute for Medical Research http://www.nimr.or.tz/

NIMR (2008) Strategic Plan III. National Institute for Medical Research http://www.nimr.or.tz/

NSGRP II (2010) National Strategy for Growth and Reduction of Poverty. Ministry of Finance and Economic Affairs. United Republic of Tanzania.

Olson, W.P. (1969) Rat-flea indices, rainfall, and plague outbreaks in Vietnam, with emphasis on the Pleikue Area. American Journal of Tropical Medicine and Hygiene 18, 621-628.

Omumbo, J.A., Lyon, B.,Waweru, S.M., Connor, S.J. \& Thomson, M.C. (2011) Raised temperatures over Kericho tea estates: revisiting the climate in the East African highlands malaria debate. Malaria Journal 10:2.

Parmenter RR, Yadav EP, Parmenter CA, Ettestad P, Gage KL. (1999) Incidence of plague associated with increased winter-spring precipitation in New Mexico. American Journal Tropical Medicine Hygiene 61, 814-821.

Patz, J.A., Campbell-Lendrum, D., Holloway, T. \& Folley, J.A. (2005) Impact of regional climate change on human health. Nature 438, 310-317.

Patz, J.A., Martens, W.J.M., Focks, D.A. \& Jettend, T.H. (1996) Dengue fever epidemic potential as projected by general circulation models of global climate change. Environmental Health Perspectives 106, 147-153.

Pham, H.V., Dang, D.T., Tran Minh, N.N., Nguyen, N.D. \& Nguyen, T.V. (2009) Correlates of environmental factors and human plague: an ecological study in Vietnam. International Journal of Epidemiology 38, 1634-1641.

Ramin, B. (2009) Slums, climate change and human health in sub-Saharan Africa. Bulletin of the World Health Organization 87, 886

REDD (2009) Reducing Emission from Deforestation and Forest Degradation.

Rueda, L.M., Patel, K.J., Axtell, R.C. \& Stinner, R.E. (1990) Temperature-dependent development and survival rates of Culex quinquefasciatus and Aedes aegypti (Diptera: Culicidae). Journal of Medical Entomology 27, 892-898.

Rush, AB. An account of the bilious remitting fever, as it appeared in Philadelphia in the summer and autumn of the year 1780. In: Medical Inquiries and Observations. Richard \& Hall, Philadelphia 1789. p.104.

Rwaguma, E.B., Lutwama, J.J., Sempla, S.D.K., Kiwanuka, N., Kamugisha, J., Okware, S., Bagambisa, G., Lanciotti, R., Roehrig, J.T., \& Gubler, D.J. (1997) Emerging Infectious Diseases 3 (1), 1 (January-March 1997).

Sang, R.C (2007) Dengue in Africa. Nairobi, Kenya, Arbovirology/Viral Haemorrhagic Fever Laboratory, Centre for Virus Research, Kenya Medical Research Institute, 2007. Available from: http:// www.tropika.net/review/061001-Dengue_in_Africa/article.pdf. [Accessed 21October 2009] 
Schmidhuber, J. \& Tubiello, F.N. (2007) Global food security under climate change. Proceedings of the National Academy of Science 104, 19703-19708.

Schoonman, L. \& Swai, E. S. (2009) Risk factors associated with the seroprevalence of leptospirosis, amongst at-risk groups in and around Tanga city, Tanzania. Annals of Tropical Medicine and Parasitology 103, 711-718.

Shongwe, S.V. (2009) The impact of climate change on health on the East, Central and Southern African (ECSA) region. Commonwealth Health Ministers' Update.

Shope, R.E. (1992) Impacts of global climate change on human health: Spread of infectious disease. Chapter 25 of Global climate change: Implications, challenges and mitigation measures, ed. S. K. Majumdar, L. S. Kalkstein, B. Yarnal, E. W. Miller, and L. M. Rosenfeld, 363-70. Easton, PA: The Pennsylvania Academy of Science.

Speranza, C.I., Kiteme, B. \& Wiesmann, U. (2008) Droughts and famines: the underlying factors and causal links among agro-pastoral households in semi-arid Makueni district, Kenya. Global Environmental Change 18, 220-233.

Stenseth, N.C., Atshabar, B.B., Begon, M., Belmain, S.R., Bertherat, E., Carniel, E., Gage, K.L., Leirs, H. \& Rahalison, L. (2008) Plague: past, present, and future. PLoS Medicine, 5:e3.

Sturrock, R.F. (1965) The development of irrigation and its influence on the transmission of Bilharziasis in Tanganyika. Bulletin of the World Health Organization 32, 225-236.

Swai, E.S. \& Schoonman, L. (2009) Prevalence of Rift Valley Fever immunoglobulin G antibody in various occupational groups before the 2007 outbreak in Tanzania. Vector-borne and Zoonotic Diseases 9, 579-582.

Taylor, B., (2009) Situation Analysis of Women, Children and the Water, Sanitation and Hygiene Sector in Tanzania. United National Children Fund.

Thompson, L., Mosley-Thompson, E. \& Mark, B. (2007) Core Project: Low latitude glacier retreat: Evidence of accelerating climate change and impacts on local to regional water resources. CWC Funded Project.

Turell, M.J. (1989) Effects of environmental temperature on the vector competence of Aedes fowleri for Rift Valley fever virus. Research in Virology 140, 147-154.

Unger, A. \& Riley, L.W. (2007) Slum health: from understanding to action. PLoS Medicine 4: e295-doi: 10.371/journal.pmed.0040295.

Urama, K.C. \& Ozor, N. (2010) Impact of Climate Change on Water Resources in Africa: the Role of Adaptation. African Technology Policy Studies.

URT (1991) The Disaster Relief Coordination Regulations. Dar es Salaam, United Republic of Tanzania.

URT (2002) National Operational Guidelines for Disaster Management (Draft Report). Prime Ministers' Office, United Republic of Tanzania, March 2002.

URT (2005) Environmental Management Act, 2004. United Republic of Tanzania

Vasilakis, N., Tesh, R.B. \& Weaver, S.C. (2008) Sylvatic dengue type 2 activity in humans, Nigeria 1966. Emerging Infectious Disease14, 502-504.

Vora, N. (2008) Impact of anthropogenic environmental alterations on vector-borne diseases. Medscape Journal of Medicine 10 (10): 238.

Wandiga, S.O., Opondo, M., Kathuri, J., Olago, D., Apindi, E., Olaka, L., Githeko, A., Githui, F., Opere, A., Ogallo, L., Marshall, M., Downs, T., Yanda, P.Z., Kangalawe, R.., Sigalla, R., Kabumbuli, R., Kiramura, E., Mugambi, P., Nanyunja, R., Baguma, T., Achola, P. (2006) Climate Change Induced Vulnerability to Malaria and Cholera in the Lake Victoria Region: Final Report for Project No. AF 91. Published by the Assessments of Impacts and Adaptations to Climate Change (AIACC). The International START Secretariat, Washington, DC. (Available at: www.aiaccproject.org)

Watson, R.T., Zinyowera, M.C. \& Moss, R.H. (1998) The Regional Impacts of Climate Change. An Assessment of Vulnerability. A Special Report of IPCC Working Group II. Cambridge, Cambridge University Press, 1998. 
WDR (2010) World Development Report 2010. Washington DC, World Bank 2009.

Weller, N., Elias, N., Dobler, G., Clowes, P., Kroidl, I., Saathoff, E., Maboko, L., Hoelscher, M. \& Heinrich, N. (2010) Epidemiology of neglected arthropod-borne viral diseases in the Mbeya Region, south-west Tanzania. Proceedings of the $24^{\text {th }}$ Annual Joint Scientific Conference, Arusha, Tanzania, March 15-18, 2010.

WHO (1986) Epidemiology and control of African trypanosomiasis. Report of a WHO expert committee. World Health Organization. Geneva, Switzerland. Technical Report Series, No. 739. $126 \mathrm{pp}$.

WHO (2001) Malaria Early Warning Systems. Concepts, Indicators and Partners: A framework for field research in Africa. WHO/CDS/RBM/2001.32, Geneva.

WHO (2008). Report on the Review of Primary Health Care in the African Region. World Health Oeganization, Geneva Switzerland.

WHO (2009) Protecting Health from Climate Change. Connecting Science, Policy and People. World Health Organization. Hppt://www.who.int.globalchange_en.

Woolhouse, M.E. \& Chandiwana, S.K. (1990) Population dynamics model for Bulinus globosus, intermediate host for Schistosoma haematobium, in river habitats. Acta Tropica 47, 151160.

Yamin, F., Rahman, A. \& Huq, S. (2005) Vulnerability, adaptation and climate disasters: a conceptual overview. IDS Bulletin 36, 1-14. 